\title{
Petrogenesis of low calcium garnet harzburgites from Kimberley, South Africa
}

\author{
C. H. Wijbrans ${ }^{1}$, G.R. Davies ${ }^{1}$, P. R.D. Mason $^{2}$ \\ ${ }^{1}$ Faculty of Earth and Life Science, Vrije Universiteit Amsterdam, $N L$ \\ ${ }^{2}$ Faculty of Geosciences, University of Utrecht, $N L$
}

Low calcium garnet harzburgite xenoliths are thought to represent some of the most basaltic-melt depleted parts of the lithospheric mantle below Archaean cratons. These rocks are of particular interest because of the frequent occurrence of sub-calcic garnets (G10) as diamond inclusions, yet sub-calcic garnets appear to be relatively rare in kimberlite xenolith suites comprising only, $2.1 \%$ of all xenoliths (Schulze, 1995). Although the garnet compositions in low calcium harzburgites overlap with those included in diamonds, garnet diamond inclusions are generally lower in $\mathrm{Ca}$, and higher in $\mathrm{Cr}$. The origin of the low $\mathrm{Ca}$ signature combined with high $\mathrm{Mg \#}$ of these xenoliths and its relation to diamond formation remains a matter of debate. Proposed models include depletion by extraction of komatiitic magmas, metamorphism of subducted serpentinised oceanic peridotites and subduction of MOR residua (i..e., shallow melting; Boyd \& Gurney, 1992; Schulze 1986, Kesson \& Ringwood, 1989).

Over the last four years a VU-DeBeers team has examined in excess of 25000 xenoliths from the Kimberley dumps specifically looking for harzburgitic xenoliths that show minor alteration and lack evidence of the almost pervasive clinopyroxene metasomatism that characterizes Kimberley xenoliths (see recent review by Simon et al, 2007). Following these criteria 14 garnet harzburgite xenoliths were selected that have varying garnet content and contain no macroscopic clinopyroxene or phlogopite. The samples have been subjected to a combined detailed petrological major and trace element study (electron microprobe, XRF and laser ablation ICP-MS) in preparation for an integrated Os-Sr-Nd-Hf and stable isotope study.

\section{Petrographic description}

Twelve Samples have equant coarse $(5-10 \mathrm{~mm})$ textures (Fig. 1a) and two are porphyroblastic. One porphyroblastic sample contains vermicular garnet that occurs in clusters (Fig 1c). The garnets in other samples are mostly round to ovoid, but vermicular grains also occur. The samples appear to be in textural equilibrium and clinopyroxene is absent except in locally developed kelyphitic rims. The mineral grains show very little if any zonation in both major and trace elements. One of the samples (AT1163) contains large euhedral Cr-spinel grains. Based on mineral modes, major and trace element, the samples are subdivided

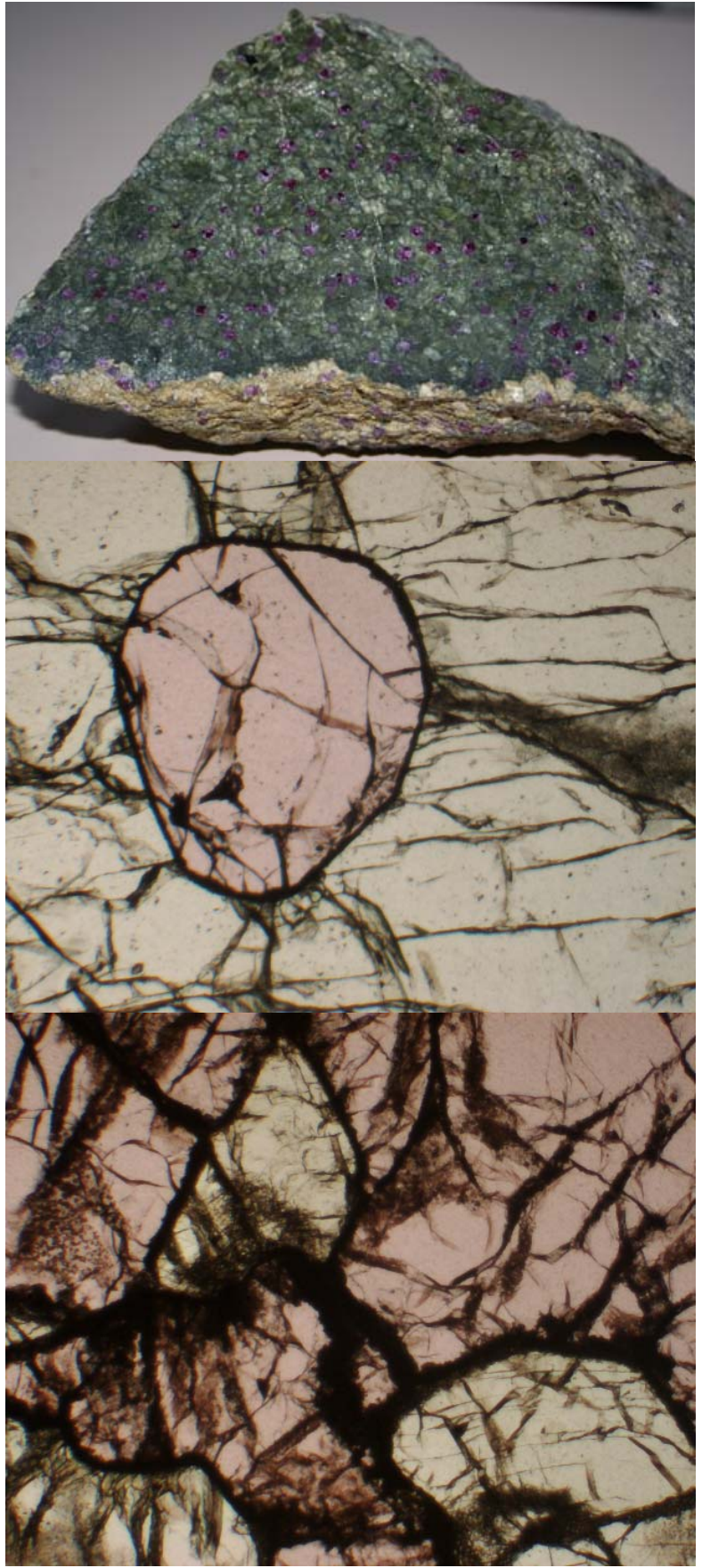

Figure 1: a) Hand specimen $(27 \mathrm{~cm})$ Group 2 sample. b) photomicrographs $(2 \mathrm{~cm})$ of garnet porphyroblast in Group 1 sample AT 1083 and c) vermicular garnet cluster in Group 1 AT $1167(0.5 \mathrm{~cm})$. 
into three groups: Group 1 (8 samples) have a relatively wide range of modal opx, between 23.3 and $34.9 \mathrm{wt} \%$, and olivine (57.3-70.1 $\mathrm{wt} \%)$, but a small range of gt; 3.7 to $6.6 \mathrm{wt} \%$. Group 2 (4 samples) have lower opx abundance (between 10 and $17 \mathrm{wt} \%$ ), 67.6$71.8 \%$ olivine and remarkably higher garnet abundance $(\sim 13 \%)$. The modal composition range within this group is small but could be due to limited sample numbers. Sample AT1163 (Group 3) is distinct with very low modal abundance of garnet $(0.14 \%)$. It has $21.9 \%$ opx, $75.7 \%$ olivine and $3.5 \mathrm{wt} \%$ spinel.

\section{Chemical Compositions}

All samples are extremely depleted in the magmaphile elements $\mathrm{FeO}, \mathrm{CaO}$ and $\mathrm{Al}_{2} \mathrm{O}_{3}$, Group 3 sample AT 1163 has the lowest concentrations $(\mathrm{CaO}=0.09$ and $\mathrm{Al}_{2} \mathrm{O}_{3}=0.2 \mathrm{wt} \%$ ), Group 1 has intermediate values with a relatively small range: $\mathrm{CaO}, 0.35-0.6 \mathrm{wt} \%$, and Group 2 the highest concentrations $\mathrm{CaO}=0.56-0.86$ wt $\%$ and $\mathrm{Al}_{2} \mathrm{O}_{3}$ 2.1-3.1 wt\%. All samples are strongly Si-enriched (whole rock $\mathrm{MgO} / \mathrm{SiO}_{2}=0.92-1.08$ ), typical of Kaapvaal (Fig. 2). Whole rock $\mathrm{MgO}$ concentrations range from 44.8 to $47.6 \mathrm{wt} \%$ in Group 1 and 2 and reach a maximum of $49.9 \mathrm{wt} \%$ in Group 3 . $\mathrm{FeO}$ concentrations range between 5.3-6.3 wt\% in Group 1 and 2, and are extremely low in Group 3 (3.9 wt $\%$ ).

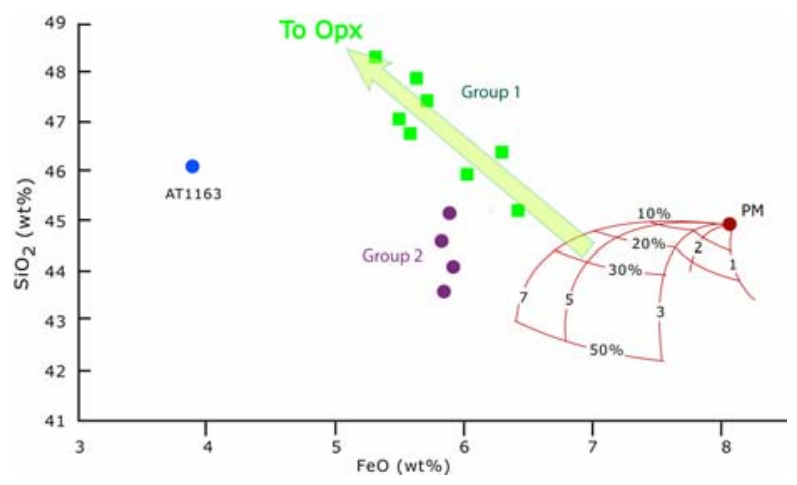

Figure 2: Whole rock $\mathrm{FeO}$ vs $\mathrm{SiO}_{2}$. Melting grid at 1 to $7 \mathrm{GPa}$ after Walter 2003.

Olivine $\mathrm{Mg} \#$ are between 91.3 and 95.6 and $\mathrm{CaO}$ contents in garnet vary from 0.7 to $5.4 \mathrm{wt} \%$. Despite the absence of clinopyroxene, garnet $\mathrm{CaO}-\mathrm{Cr}_{2} \mathrm{O}_{3}$ relationships suggest that 5 garnet harzburgites have garnets in equilibrium with clinopyroxene (Sobolev et al, 1973). Calculated pressures and temperatures are between $3.4 \mathrm{GPa}\left(865^{\circ} \mathrm{C}\right)$ and $5.0 \mathrm{GPa}\left(1087^{\circ} \mathrm{C}\right)$ and are within error of the Kalahari geotherm (Rudnick and Nyblade, 1999).

Calculated garnet-opx trace element partition coefficients are comparable to literature values (e.g., Glaser et al. 1999) and demonstrate that garnet and opx are in chemical equilibrium giving credence to the calculated P-T estimates. Whole rock trace element concentrations were constructed from mineral modes and in situ garnet and opx compositions (Fig. 3).
Except AT 1163, all samples are characterized by sinusoidal REE patterns with generally sub-chondritic concentrations. Group 1 samples have low $\mathrm{La}_{\mathrm{N}}$ between 0.015 and 0.05 with maxima at $\mathrm{Nd}_{\mathrm{N}}$ or $\mathrm{Sm}_{\mathrm{N}}$ (0.7 to 1.3) and low HREE $\mathrm{H}_{\mathrm{N}} ; \mathrm{Yb}_{\mathrm{N}}=0.04$ to 0.09 . Group 2 samples are similar with maxima at $\mathrm{Nd}_{\mathrm{N}}$ or $\mathrm{Sm}_{\mathrm{N}}(0.069$ to 0.096$)$, relatively low $\mathrm{Gd}_{\mathrm{N}}$ and $\mathrm{Dy}_{\mathrm{N}}$ $\left(\mathrm{Gd}_{\mathrm{N}}\right.$ 0.10-0.60) but notably relatively high $\mathrm{HREE}_{\mathrm{N}}$ $\left(\mathrm{Yb}_{\mathrm{N}}=0.8-1.0\right)$. Group 3 has the lowest REE contents with only a slight enrichment in $\mathrm{LREE}_{\mathrm{N}}: \mathrm{La}_{\mathrm{N}}=0.07$, peak at $\mathrm{Nd}_{\mathrm{N}}$ at $0.12, \mathrm{Lu}_{\mathrm{N}}=0.018$. The garnet of this sample has a concave upward $\mathrm{REE}_{\mathrm{N}}$ pattern with $\mathrm{La}_{\mathrm{N}}=$ 2.4, $\mathrm{Eu}_{\mathrm{N}}=45.2$ and $\mathrm{Lu}_{\mathrm{N}}=9.8$.

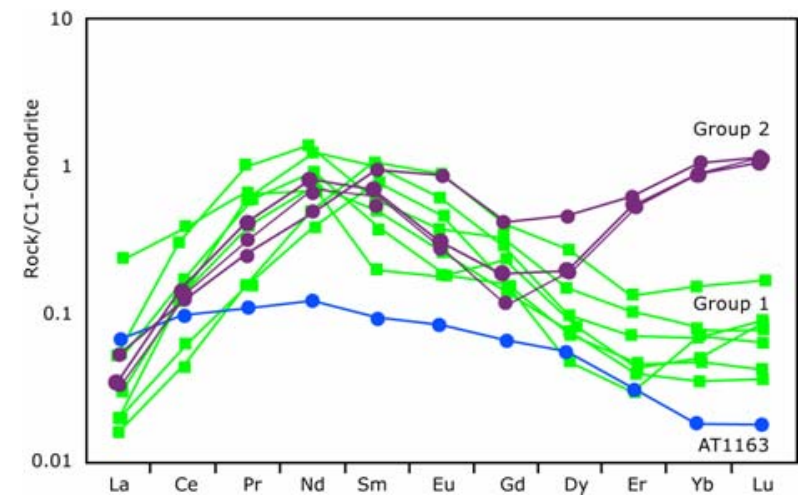

Figure 3: Calculated whole rock REE patterns for garnet harzburgites.

\section{Discussion}

The whole rock major element data are extremely depleted in magmaphile elements, which coupled with high $\mathrm{MgO}$ and high $\mathrm{Mg} \#$ of olivine suggests 35 to $50 \%$ melt depletion. Current polybaric melting models (e.g. Walter 2003), however, cannot explain the low FeO and high $\mathrm{SiO}_{2}$. These samples therefore appear strongly effected by the Si-metasomatism that produces opx addition and associated low $\mathrm{FeO}$, a characteristic of much of the Kaapvaal Craton (Boyd 1989).

Despite the garnet bearing nature of all the samples, the low abundances of moderately incompatible elements (Sc, HREE) suggest extensive melting in the absence of garnet. HREE modeling indicates that a minimum of $20 \%$ melting in the spinel stability field is required to explain Group 1 samples and up to $27.5 \%$ melting for Group 3 (Fig. 4). The extreme Mg\# of olivine in Group 3 (95.6) suggests melting was in excess of $50 \%$ (Berstein et al., 2007). The metasomatic modification of all samples, however, means it is difficult to constrain the extent of any initial melting in the garnet stability field. It is highly probable that polybaric melting started in the garnet stability field, but it is not possible to erect quantitative melting models from the trace element data. A combination of the HREE evidence with olivine $\mathrm{Mg \#}$ data suggests qualitative models for Group 1 and 3 samples involving $>20 \%$ melting in the garnet stability field followed by 20 to $30 \%$ melting in the spinel stability field, i.e. $\geq 40 \%$ total melt extraction. 


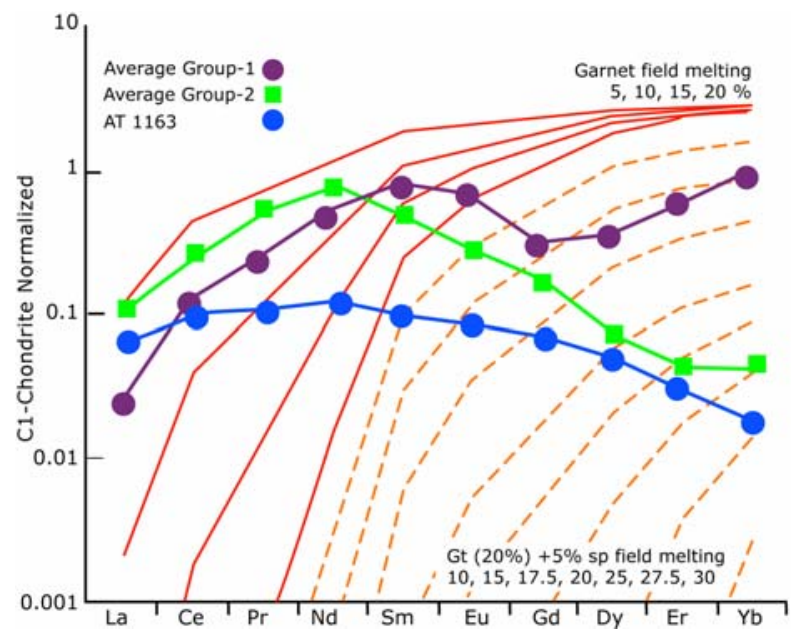

Figure 4. REE modeling of HREE depletion following Hellebrand et al. 2002 and Simons et al. 2007.

Group 2 samples do not show the same depletion in HREE, which could indicate a larger proportion of melting took place in the presence of residual garnet. The low $\mathrm{Er} / \mathrm{Lu}_{\mathrm{N}}$ of 0.5 for the three samples indicates that garnet was important in the petrogenesis of these samples. REE data alone could be explained by $20 \%$ melting in the garnet stability field, followed by $10 \%$ of melting in the spinel stability field. However, Group 2 samples are characterized by high $\mathrm{Al} / \mathrm{Si}$ ratios (Fig 5) and high garnet modes that suggest that the samples have been subjected to garnet addition rather than extensive melting in the garnet stability field. The relatively high HREE abundances are therefore interpreted to indicate metasomatic garnet addition.

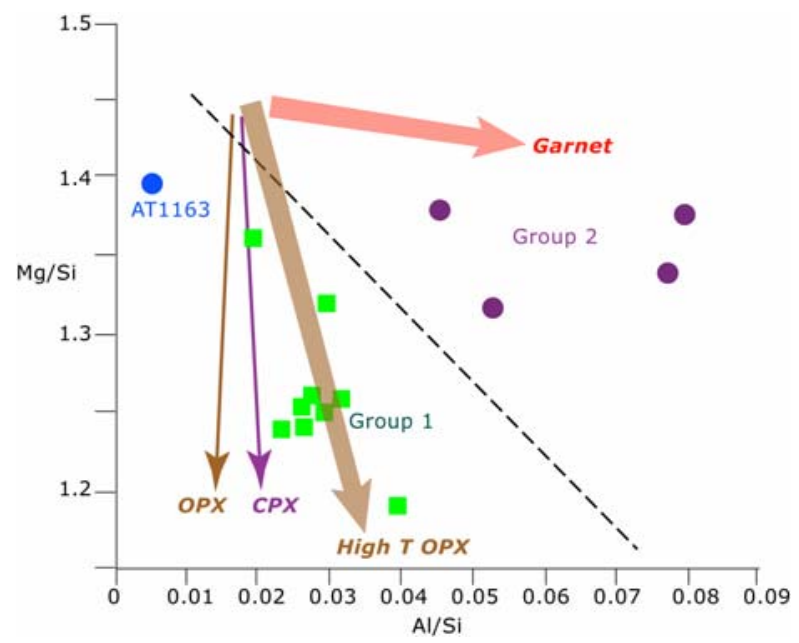

Figure 5: Major element variations of garnet harburgites. Dashed line is the inferred melt extraction line defined by abyssal peridotites and off craton peridotite xenoliths.

\section{Conclusions}

Garnet harzburgites from Kimberley record multiple petrogenetic histories. The majority (Group 1) are the consequence of $\geq 40 \%$ total melt extraction at least partly in the spinel stability field. Subsequent silica enrichment is probably related to LREE enrichment in a subduction zone setting and subsequent tectonic transport to the garnet stability zone where metamorphic reactions between opx and spinel led to the formation of sub-calcic garnets. The occurrence of supposedly syngenetic G10 garnets inclusions in diamonds is hard to reconcile with this model unless silicification, metamorphism and diamond growth are synchronous. Group 2 harzburgites reveal clear evidence of garnet addition and suggest interaction between spinel harzburgites and a silicate melt. The extreme melt extraction inferred from Group 1 and 3 samples (40 to $>50 \%$ ) is incompatible with current adiabatic melting models, even under Archaean mantle temperatures. This strongly implies that multiple melting events and that water plays a significant role, i.e. further evidence for a subduction related tectonic setting.

\section{References}

Bernstein, S., Kelemen, P.B., Hanghøj, K., 2007. Consistent olivine $\mathrm{Mg} \#$ in cratonic mantle reflects Archean mantle melting to the exhaustion of orthopyroxene. Geology 35, 459-462.

Boyd, F.R., Gurney J.J, 1993. Diamonds and the African lithosphere. Science 232 472-477.

Canil, D., 1992. Constraints on the origin of mantle-derived low Ca garnets Contributions to Mineralogy and Petrology 109: 421-430

Glaser, S.M. et al., 1999. Trace element compositions of minerals in garnet and spinel peridotite from the Vitim volcanic field, Transbaikalia, eastern Siberia, Lithos, 48.

Hellebrand, E., Snow, J.E., Hoppe, P., Hofmann, A.W, 2002. Garnet-field Melting and Late-stage Refertilization in 'Residual' Abyssal Peridotites from the Central Indian Ridge, Journal of petrology 43, 2305-2338.

Kesson S. Ringwood A.E. 1989. Slab-mantle interactions2: the formation of diamonds. Chemical Geology 78 : 97-118.

Rudnick, R.L., Nyblade, A.A. 1999. The thickness and heat production in Archean lithosphere: constraints from xenolith thermobarometry and surface heat flow. Mantle Petrology: Field Observations and High Pressure Experimentation, 3-12.

Schulze D.J., 1986. Calcium anomalies in the mantle and a subducted metaserpentinite origin for diamonds. Nature 319, $483-485$.

Schulze, D.J., 1995. Low-Ca Harzburgites from Kimberley South-Africa: Abundance and bearing on the structure and evolution of the lithosphere journal of Geophysical Research, 100, 12513-12526.

Simon, N.S.C., Carlson, R.W., Pearson, D.G., Davies, G.R., 2007. The origin and evolution of the Kaapvaal cratonic lithospheric mantle. Journal of Petrology 48, 589-625.

Sobolev, N.V., Lavrent'ev, Y.u.G., Pokhilenko, N.P., Usova, L.V., 1973. Chrome-rich garnets from the kimberlites of Yakutia and their paragenesis. Contributions to Mineralogy and Petrology 40, 39- 52.

Walter, M.J., 2003. Melt extraction and compositional variability in Mantle Lithosphere, Treaties on Geochemistry, 363-394. 